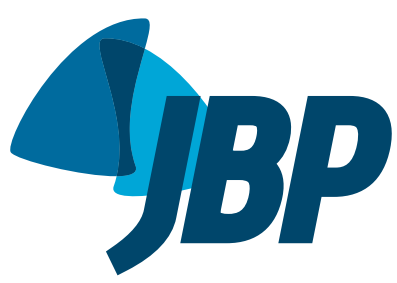

1. Divisão de Pesquisa Populacional, Instituto Nacional de Câncer José de Alencar Gomes da Silva - INCA - Rio de Janeiro (RJ) Brasil.

2. Comissão Nacional para Implementação da Convenção-Quadro de Controle do Tabaco no Brasil, Instituto Nacional de Câncer José de Alencar Gomes da Silva - INCA - Rio de Janeiro (RJ) Brasil.

a. iD http://orcid.org/0000-0003-1903-6188

b. iD http://orcid.org/0000-0003-0866-4672

Submitted: 25 October 2017 Accepted: 28 January 2018.

Study carried out at the Instituto Nacional de Câncer José de Alencar Gomes da Silva - INCA - Rio de Janeiro (RJ) Brasil.

\title{
Noncompliance with the law prohibiting the sale of cigarettes to minors in Brazil: an inconvenient truth
}

\author{
André Salem Szklo ${ }^{1, a}$,Tânia Maria Cavalcante ${ }^{2, b}$
}

\begin{abstract}
Objective: To draw up an up-to-date scenario of compliance with the law prohibiting the sale of cigarettes to minors. Methods: We used data about youth access to cigarette purchase that were obtained through a nationwide survey conducted in 2015 among students aged 13-17 years. We estimated simple proportions of attempts to buy cigarettes, success of attempts, purchase of cigarettes on a regular basis, and purchase of cigarettes on a regular basis in a store or bar. All estimates were stratified by gender, age group, and Brazilian macro-region. Crude absolute difference and adjusted absolute difference in the proportion of smokers in each category by variable of interest were analyzed by a generalized linear model with binomial distribution and identity link function. Results: Approximately 7 in every 10 adolescent smokers attempted to buy cigarettes at least once in the 30 days prior to the survey. Of those, approximately 9 in every 10 were successful, and individuals aged 16-17 years (vs. those aged 13-15 years) were less often prevented from buying cigarettes (adjusted absolute difference, 8.1\%; $p \leq$ $0.05)$. Approximately $45 \%$ of all smokers aged $13-17$ years in Brazil reported buying their own cigarettes on a regular basis without being prevented from doing so, and, of those, $80 \%$ reported buying them in a store or bar (vs. from a street vendor). Conclusions: Our findings raise an important public health concern and may contribute to supporting educational and surveillance measures to enforce compliance with existing anti-tobacco laws in Brazil, which have been disregarded.

Keywords: Smoking/epidemiology; Smoking/legislation \& jurisprudence; Adolescent

behavior; Public health.
\end{abstract}

\section{INTRODUCTION}

Brazil has achieved great advances in the fight against the tobacco epidemic in recent years because of the implementation of a series of legislative and educational measures based on the World Health Organization Framework Convention on Tobacco Control. ${ }^{(1-4)}$

The reduction in the proportion of smokers reflects not only increased smoking cessation but also a likely decrease in smoking initiation among adolescents and young adults. ${ }^{(4)}$ In fact, Brazilian national data from recent household surveys have shown a reduction in the proportion of smokers aged 18 to 24 years, which decreased from $13.6 \%$ to $10.6 \%$ from 2008 to 2013 , as well as a reduction in the proportion of cigarette use among adolescents aged 14 to 17 years, which decreased from $6.2 \%$ to $3.4 \%$ from 2006 to 2012. . $^{(4,5)}$

Given that the mean age at initiation of regular cigarette smoking in Brazil is around 16 years, ${ }^{(6)}$ it is of fundamental importance that compliance with the law prohibiting the sale of cigarettes to minors be periodically assessed. ${ }^{(7,8)}$ It has been observed, for example, that, despite the reduction in the proportion of adolescent smokers that occurred in Brazil between 2006 and 2012,(5) surveys conducted among students aged 13 to 15 years in several Brazilian cities between 2002 and 2009 indicated that compliance with the law prohibiting the sale of cigarettes to children and adolescents was pretty far from ideal. ${ }^{(9)}$ In fact, among the adolescent smokers who had tried to buy cigarettes in the 30 days prior to the surveys, the proportion of those who reported that they had not been prevented from buying cigarettes ranged from $51.0 \%$ to $91.6 \%$. This suggests that the proportions of adolescent smokers in Brazil could have been further reduced. In addition, in 2012 and 2015, comparative national data on the proportion of cigarette consumption among students aged 13 to 15 years signaled a reversal of the decrease in smoking initiation among youth (5.1\% vs. 5.6\%). ${ }^{(10,11)}$

The objective of the present study was, therefore, to draw up an up-to-date scenario of compliance/noncompliance with the law prohibiting the sale of cigarettes to minors. To that end, we used data about youth access to cigarette purchase that were obtained through a nationwide survey conducted in 2015 among students aged 13 to 17 years. ${ }^{(11)}$ This study may contribute not only to the understanding of the course of the smoking epidemic in Brazil but may also provide grounds for action, if necessary, toward the effective implementation of this law.

\section{METHODS}

We used data from the Pesquisa Nacional de Saúde do Escolar (PeNSE, Brazilian National School-Based Adolescent Health Survey), conducted in 2015, to 
assess compliance with the law prohibiting the sale of cigarettes to minors in Brazil. ${ }^{(11)}$

The PeNSE is a survey of students that was first conducted in 2009 and occurs every 3 years in Brazil. Important innovations were introduced into the 2015 edition of the PeNSE.One of the most significant was that data were derived from a sample that included sixth to ninth graders and tenth to twelfth graders at public and private schools nationwide. Details regarding the cluster sampling procedure can be obtained elsewhere. ${ }^{(11)}$ The indicators used in the present study concern the 13- to 17-year age group, totaling 10,926 questionnaires.

Although the cigarette consumption-related themes investigated in 2015 are the same as those of the previous editions of the survey, in that year, two new questions regarding youth access to cigarettes were also included: "In the past 30 days, did anybody refuse to sell you cigarettes (at any time) because of your age?"-the response choices were as follows: "I did not try to buy cigarettes in the past 30 days" OR "Yes, someone refused to sell me cigarettes because of my age" OR "No, my age did not keep me from buying cigarettes"; and "In the past 30 days, how did you usually get your own cigarettes?"-the response choices were as follows: "I bought them in a store or bar" OR "I bought them from a street vendor" OR "I gave someone else money to buy them for me" OR "I borrowed them from someone else" OR "An older person gave them to me" OR "I got them some other way".

\section{Data analysis}

The analysis of the variables regarding youth access to cigarettes was restricted to the adolescents who reported having smoked cigarettes in the past 30 days ( $n=688)$. The adolescent smokers were separated into two age groups (13- to 15 -year olds vs. 16- to 17-year olds) in order to assess the impact that the individual's physical aspect, related to growth and hormonal maturity, has on the attempts to buy cigarettes and, subsequently, on the success (or failure) of those attempts.

We estimated simple proportions of the following variables: "attempts to buy"; "success of attempts"; "purchase on a regular basis"; and "purchase on a regular basis in a store or bar." All estimates were stratified by gender, age group, and Brazilian macroregion. To that end, we created a dichotomous variable called "attempts to buy", classified as follows: (1) a combination of individuals who were prevented from buying cigarettes sometime in the 30 days prior to the completion of the questionnaire and those who were not prevented from doing so; and $(0)$ individuals who did not attempt to buy cigarettes during that period.

We also created another dichotomous variable called "success of attempts", which was classified as follows: (1) individuals who were not prevented from buying cigarettes in the 30 days prior to the survey; and (0) individuals who were prevented from buying cigarettes during that period.

In addition, for the adolescent smokers who reported having been able to buy cigarettes sometime in the 30 days prior to the survey, we created a dichotomous variable called "purchase on a regular basis", described as follows: (1) individuals who reported having bought cigarettes usually from a store, bar, or street vendor during that period; and (0) individuals who reported having gotten cigarettes through means other than a purchase during that period.

Finally, for the adolescent smokers who were not prevented from buying cigarettes in the 30 days prior to the survey, we created a dichotomous variable called "purchase on a regular basis in a store or bar", as follows: (1) individuals who bought cigarettes in a store or bar during that period; and (0) individuals who bought cigarettes on a regular basis from a street vendor during that period.

Crude absolute difference and adjusted absolute difference in the proportion of smokers in each category by gender, age group, and Brazilian macro-region were analyzed by a generalized linear model with binomial distribution and identity link function. ${ }^{(12)}$ In this model, "attempts to buy" (OR "success of attempts" OR "purchase on a regular basis" or "purchase in a store or bar") was used as a dependent variable, whereas gender, age group, and Brazilian macro-region were used as independent variables. Confidence intervals for adjusted absolute differences obtained from the regression model were calculated on the basis of a type I error of $5 \%$. Additive interactions among independent variables were assessed by inclusion of corresponding interaction terms. The choice of an additive model, including for assessing interactions, was based on the importance of the results from the standpoint of prevention of youth access to cigarettes. ${ }^{(13)}$

Variables were processed and data were analyzed using STATA 12.0 (StataCorp LP, College Station, TX, USA). ${ }^{(14)}$ The STATA svy command was used in order to handle cluster sampling appropriately and allow introduction of expansion fractions in the analyses.

The 2015 PeNSE ${ }^{(11)}$ was approved by the Brazilian National Health Council-Comissão Nacional de Ética em Pesquisa (CONEP, Brazilian National Research Ethics Committee; no. 1.006 .467 of $03 / 30 / 2015$ ).

\section{RESULTS}

Among the approximately 810,000 adolescent smokers who reported having smoked cigarettes in the past 30 days prior to the survey, there were higher proportions of 13- to 15-year-olds (vs. 16- to 17-year-olds), males, and Southeastern students (Table 1).In 2015, the proportion of smokers among students aged 13 to 17 years in Brazil was estimated to be $6.6 \%$ (the proportions of smokers among 13- to 15-year-olds and among 16- to 17-year-olds were estimated to be $5.4 \%$ and $8.4 \%$, respectively). 
Approximately 7 in every 10 smokers aged 13 to 17 years tried to buy cigarettes at least once in the 30 days prior to the survey; this proportion was significantly lower among girls (adjusted absolute difference, $-9.5 \% ; \mathrm{p} \leq 0.05$; Table 2).

Of the adolescent smokers who tried to buy cigarettes sometime in the past 30 days, approximately 9 in every 10 were successful (Table 3 ). We also found that the adolescents aged 16 to 17 years were less often prevented from buying cigarettes than were the younger ones (adjusted absolute difference, $8.1 \% ; p \leq$

Table 1. Distribution of the individuals who reported having smoked in the 30 days prior to the survey, by age group, gender, and Brazilian macro-region.

\begin{tabular}{|c|c|c|c|}
\hline \multirow[t]{2}{*}{ Characteristic } & \multicolumn{3}{|c|}{ Result } \\
\hline & $\mathbf{n}^{\mathrm{a}}$ & $n^{b}$ & $\%^{c}$ \\
\hline Total & 688 & 807,676 & - \\
\hline \multicolumn{4}{|l|}{ Age group, years } \\
\hline $13-15$ & 379 & 414,032 & 51.3 \\
\hline $16-17$ & 309 & 393,644 & 48.7 \\
\hline \multicolumn{4}{|l|}{ Gender } \\
\hline Male & 373 & 432,003 & 54.4 \\
\hline Female & 315 & 375,673 & 45.6 \\
\hline \multicolumn{4}{|l|}{ Region } \\
\hline North & 104 & 73,376 & 8.9 \\
\hline Northeast & 105 & 169,823 & 22.3 \\
\hline Southeast & 151 & 354,090 & 43.2 \\
\hline South & 168 & 135,461 & 16.6 \\
\hline Central-West & 160 & 74,926 & 8.9 \\
\hline
\end{tabular}

Brazilian Institute of Geography and Statistics. (11) anly 4 individuals did not answer whether they had smoked in the 30 days prior to the survey and were excluded from the analysis. ' Number of smokers taking sample weight into account. cProportion of smokers taking sample weight into account.
0.05).In addition, when compared with the adolescent smokers attending schools in the Southeast, South, or Central-West, those attending schools in the Northeast reported a higher proportion of success in purchasing cigarettes.

Of the adolescent smokers who reported having been able to buy cigarettes at least once in the 30 days prior to the survey, approximately 7 in every 10 said that they did it regularly, that is, they usually got their own cigarettes by buying them directly from a store, bar, or street vendor. We found that the proportion of this behavior was considerably higher among the smokers aged 16 to 17 years than among those aged 13 to 15 years (adjusted absolute difference, $24.5 \%$; $\mathrm{p} \leq$ 0.05).In addition, the adolescent smokers attending schools in the Northeast apparently had the lowest proportion of "purchase on a regular basis" (Table 4).

Among the adolescents whose most common mode of cigarette acquisition in the 30 days prior to the survey was direct purchase, approximately 8 in every 10 reported having bought cigarettes in a store or bar (vs. from a street vendor). The smokers aged 16 to 17 years (in comparison with those aged 13 to 15 years) and the adolescent smokers attending schools in the Southeast, South, or Central-West of Brazil (in comparison with those attending schools in the Northeast) reported having bought cigarettes on a regular basis and more often in a store or bar than from a street vendor (Table 5).

\section{DISCUSSION}

The results presented here paint a dismal picture of the effectiveness of the implementation of the law prohibiting the sale of tobacco products to minors in Brazil. Approximately 7 in every 10 adolescent smokers

Table 2. Crude absolute difference $(A D)$ and adjusted $A D$ in the proportion of smokers who tried to buy cigarettes sometime in the 30 days prior to the survey, by age group, gender, and Brazilian macro-region.

\begin{tabular}{|c|c|c|c|}
\hline \multirow[t]{2}{*}{ Characteristic } & \multicolumn{3}{|c|}{ Smokers $^{a}$} \\
\hline & $\%(95 \% \mathrm{CI})$ & Crude AD & Adjusted AD* \\
\hline Total & $72.3(67.5-76.6)$ & - & - \\
\hline \multicolumn{4}{|l|}{ Age group, years } \\
\hline $13-15$ & $71.0(64.3-76.8)$ & Ref. & Ref. \\
\hline $16-17$ & $73.6(66.4-79.7)$ & 2.6 & 2.2 \\
\hline \multicolumn{4}{|l|}{ Gender } \\
\hline Male & 76.5 (72.1-79.8) & Ref. & Ref. \\
\hline Female & $67.4(62.0-72.0)$ & $-9.1^{* *}$ & $-9.5^{* *}$ \\
\hline \multicolumn{4}{|l|}{ Region } \\
\hline North & $77.3(66.5-85.5)$ & 2.9 & 2.3 \\
\hline Northeast & $74.4(63.9-82.7)$ & Ref. & Ref. \\
\hline Southeast & $68.8(59.7-76.6)$ & -5.6 & -6.8 \\
\hline South & $75.3(67.9-81.7)$ & 0.8 & 1.0 \\
\hline Central-West & $73.3(65.1-80.2)$ & -1.1 & -1.6 \\
\hline
\end{tabular}

Brazilian Institute of Geography and Statistics. ${ }^{(11)}$ anly 3 individuals did not answer whether they had tried to buy cigarettes sometime in the 30 days prior to the survey and were excluded from the analysis. Adolescent smokers who reported having gotten cigarettes usually by buying them from a store, bar, or street vendor in those 30 days and who also reported that they did not try to buy cigarettes (at any time) in the past 30 days were reclassified and combined with those who tried to buy cigarettes sometime in the past 30 days $(n=20)$ *Age-, gender-, and region-adjusted generalized linear model, as appropriate, with binomial distribution and identity link function. No interaction term was statistically significant. $* * p \leq 0.05$. 
Table 3. Crude absolute difference (AD) and adjusted AD in the proportion of smokers who were not prevented from buying cigarettes at any time in the 30 days prior to the survey, by age group, gender, and Brazilian macro-region, among the smokers who tried to buy cigarettes sometime in the 30 days prior to the survey.

\begin{tabular}{|c|c|c|c|}
\hline \multirow[t]{2}{*}{ Characteristic } & \multicolumn{3}{|c|}{ Smokers $^{a}$} \\
\hline & $\%(95 \% \mathrm{CI})$ & Crude AD & Adjusted AD* \\
\hline Total & 86.1 (81.5-89.7) & - & - \\
\hline \multicolumn{4}{|l|}{ Age group, years } \\
\hline $13-15$ & $82.3(79.4-85.6)$ & Ref. & Ref. \\
\hline $16-17$ & 89.9 (85.9-93.9) & $7.6^{* *}$ & $8.1^{* *}$ \\
\hline \multicolumn{4}{|l|}{ Gender } \\
\hline Male & 85.7 (78.8-90.6) & Ref. & Ref. \\
\hline Female & $86.6(80.1-91.2)$ & 0.9 & 1.2 \\
\hline \multicolumn{4}{|l|}{ Region } \\
\hline North & $85.6(74.5-92.4)$ & -8.3 & -8.0 \\
\hline Northeast & $93.9(88.5-95.0)$ & Ref. & Ref. \\
\hline Southeast & $83.9(75.8-88.0)$ & $-10.0^{* *}$ & $-10.3^{* *}$ \\
\hline South & $82.8(74.3-88.3)$ & $-11.1^{* *}$ & $-11.8^{* *}$ \\
\hline Central-West & $84.4(77.5-88.5)$ & $-9.5^{* *}$ & $-9.6^{* *}$ \\
\hline
\end{tabular}

Brazilian Institute of Geography and Statistics. ${ }^{(11)}$ anly 3 individuals did not answer whether they had tried to buy cigarettes sometime in the 30 days prior to the survey and were excluded from the analysis. Adolescent smokers who reported having bought cigarettes usually from a store, bar, or street vendor in the past 30 days and who also reported that they were prevented from buying them (sometime) in the past 30 days were reclassified and combined with those who were not prevented from buying cigarettes in the past 30 days because of their age $(n=$ 73). *Age-, gender-, and region-adjusted generalized linear model, as appropriate, with binomial distribution and identity link function. No interaction term was statistically significant. **p $\leq 0.05$.

Table 4. Crude absolute difference (AD) and adjusted $A D$ in the proportion of smokers who usually bought cigarettes

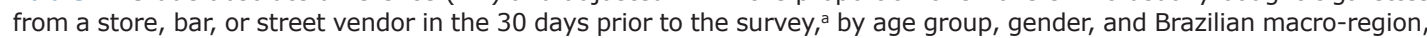
among the smokers who were not prevented from buying cigarettes at any time in the 30 days prior to the survey.

\begin{tabular}{|c|c|c|c|}
\hline \multirow[t]{2}{*}{ Characteristic } & \multicolumn{3}{|c|}{ Smokers $^{b}$} \\
\hline & $\%(95 \% \mathrm{CI})^{\mathrm{b}}$ & Crude AD & Adjusted AD* \\
\hline Total & $69.5(63.1-75.2)$ & - & - \\
\hline \multicolumn{4}{|l|}{ Age group, years } \\
\hline $13-15$ & $56.7(47.4-65.7)$ & Ref. & Ref. \\
\hline $16-17$ & $81.2(73.1-87.2)$ & $24.5^{* *}$ & $24.4^{* *}$ \\
\hline \multicolumn{4}{|l|}{ Gender } \\
\hline Male & $74.7(68.8-79.0)$ & Ref. & Ref. \\
\hline Female & $62.9(55.8-68.7)$ & $-11.8^{* *}$ & -10.1 \\
\hline \multicolumn{4}{|l|}{ Region } \\
\hline North & $79.6(68.8-85.1)$ & $20.3^{* *}$ & $24.6^{* *}$ \\
\hline Northeast & $59.3(48.0-68.5)$ & Ref. & Ref. \\
\hline Southeast & $71.6(59.7-81.1)$ & 12.3 & 11.7 \\
\hline South & $72.5(62.1-80.3)$ & 13.2 & 13.8 \\
\hline Central-West & $70.0(58.2-79.6)$ & 10.7 & 12.0 \\
\hline
\end{tabular}

Brazilian Institute of Geography and Statistics. ${ }^{(11)}$. ${ }^{a}$ Versus other acquisition options as follows: "I gave someone else money to buy cigarettes for me" OR "I borrowed them from someone else" OR "I took it without permission" OR "An older person gave them to me" OR "I got them some other way". bOnly 3 individuals did not answer whether they had tried to buy cigarettes sometime in the 30 days prior to the survey and were excluded from the analysis. *Age-, gender-, and region-adjusted generalized linear model, as appropriate, with binomial distribution and identity link function. No interaction term was statistically significant. **p $\leq 0.05$.

felt motivated to try at least once to break this law. Even worse, the vast majority of those who chose to venture into this illegal behavior were rewarded by encountering no great resistance from retailers and/ or street vendors to them purchasing cigarettes; to make matters further worse, a substantial proportion of those same adolescents reported buying cigarettes on a regular basis. As expected, the closer adolescents were to adulthood (age 16-17 years), the greater the likelihood of them not being prevented from buying cigarettes because of their age and, consequently, of them doing so more regularly and in licensed places, such as stores or bars. When we applied specific proportions of each of these factors listed above, we found that approximately $45 \%$ of all adolescent smokers aged 13 to 17 years in Brazil reported buying their own cigarettes on a regular basis without being prevented from doing so. 
Table 5. Crude absolute difference (AD) and adjusted AD in the proportion of smokers who usually bought cigarettes from a store or bar in the 30 days prior to the survey, ${ }^{a}$ by age group, gender, and Brazilian macro-region, among the smokers who were not prevented from buying cigarettes at any time in the 30 days prior to the survey and who purchased cigarettes on a regular basis in those 30 days.

\begin{tabular}{|c|c|c|c|}
\hline \multirow[t]{2}{*}{ Characteristic } & \multicolumn{3}{|c|}{ Smokers $^{b}$} \\
\hline & $\%$ (95\% CI) & Crude AD & Adjusted AD* \\
\hline Total & $81.1(74.2-86.5)$ & - & - \\
\hline \multicolumn{4}{|l|}{ Age group, years } \\
\hline $13-15$ & 73.7 (64.2-79.6) & Ref. & Ref. \\
\hline $16-17$ & $85.9(79.7-89.8)$ & $12.2^{* *}$ & $11.3^{* *}$ \\
\hline \multicolumn{4}{|l|}{ Gender } \\
\hline Male & 83.7 (75.1-89.7) & Ref. & Ref. \\
\hline Female & $77.3(65.0-86.2)$ & -6.4 & -5.4 \\
\hline \multicolumn{4}{|l|}{ Region } \\
\hline North & $75.2(50.5-90.0)$ & 10.0 & 12.3 \\
\hline Northeast & $65.2(52.0-75.4)$ & Ref. & Ref. \\
\hline Southeast & $85.1(75.5-95.0)$ & $19.9^{* *}$ & $19.4^{* *}$ \\
\hline South & $90.6(80.2-95.8)$ & $25.4^{* *}$ & $25.7^{* *}$ \\
\hline Central-West & $87.2(75.8-94.9)$ & $22.0^{* *}$ & $22.6^{* *}$ \\
\hline
\end{tabular}

Brazilian Institute of Geography and Statistics. ${ }^{(11)}$ aVersus the smokers who usually bought cigarettes from a street vendor. 'only 3 individuals did not answer whether they had tried to buy cigarettes sometime in the 30 days prior to the survey and were excluded from the analysis. *Age-, gender-, and region-adjusted generalized linear model, as appropriate, with binomial distribution and identity link function. No interaction term was statistically significant. $* * \mathrm{p} \leq 0.05$

Recent comparative data from a study of Brazilian students aged 12 to 17 years conducted between 2013 and 2014 ${ }^{(15)}$ and from the 2015 PeNSE$^{(11)}$ suggest a trend toward an increase in the proportion of adolescent smokers ( $5.7 \%$ and $6.6 \%$, respectively). It is worth noting that the proportion of adolescent smokers reflects the sum of the effectiveness of a series of tobacco control policies aimed at reducing smoking initiation that are currently in effect in Brazil. For example, it is likely that the new structure of tobacco product taxation implemented in 2012 has contributed enormously to discouraging adolescents from starting smoking. ${ }^{(16,17)}$ In addition, the regulation that prohibited smoking in enclosed collective areas as of late $2014^{(18)}$ may have contributed to a further reduction in the social acceptability of smoking in bars and nightclubs, which are places where many youth start smoking. However, low compliance with the law prohibiting youth access to tobacco products may be undermining the effects of the Brazilian national tobacco control policy measures on the prevention of smoking initiation by adolescents.

Although cigarette packs contain a warning about legislation prohibiting the sale of cigarettes to minors, data from the PeNSE ${ }^{(11)}$ indicate that there is a great deal of irresponsibility on the part of retailers and that compliance with the law is poorly enforced by the responsible agencies. This situation is aggravated by the widespread availability of points of sale, ${ }^{(19)}$ by the tobacco industry point-of-sale marketing strategies for placement of cigarette packs always next to candy, and by the suspension of the Brazilian National Health Oversight Agency resolution that, in 2012, prohibited the addition of sweet flavors to cigarettes. ${ }^{(20)}$ In addition, there has been an exponential growth in the availability of contraband tobacco products, which are sold at very low prices in stores, in bars, and mainly by street vendors. ${ }^{(21)}$

It is of note that the PeNSE(11) questions related to youth access to cigarettes also address another practice that is in violation of current laws, that is, the sale of single cigarettes. In fact, Law no. 7212/2010 establishes that, in Brazil, cigarettes must be sold, as well as displayed for sale, only in packs of 20 units. ${ }^{(22)}$ Buying a single cigarette, even if at a higher per-unit price, but still at a lower price than that of a whole pack, with no health warning attached, ${ }^{(23)}$ facilitates smoking initiation and cigarette use on a regular basis. Surveys among ninth graders (aged 13-15 years) conducted in several Brazilian cities between 2002 and 2009 indicated that, in fact, buying single cigarettes is a widespread practice in Brazil, with rates reaching above $90 \%$ in some cities. ${ }^{(9)}$

Because the effect of tobacco use is cumulative, our findings raise an important public health concern, since smoking is a risk factor that has a major impact on the burden of chronic non-communicable diseases. ${ }^{(24)}$ In fact, a recent study indicated that, in 2015, approximately 156,000 people died from diseases directly related to smoking in Brazil. (25) Another nationwide study found that, in 2013, there were approximately 280,000 "all-cause deaths" directly or indirectly attributable to smoking in Brazil(26); in addition, that study showed that the cumulative risk of mortality from COPD or lung cancer in Brazil, both for men and women, is more than 20 times higher in smokers than in nonsmokers. ${ }^{(26)}$

The limitations of the present study lie in the fact that the cross-sectional nature of the PeNSE(11) prevents us from establishing any temporal or causal relationship between findings. However, even if cigarette experimentation was not stimulated by violation of 
the law prohibiting the sale of cigarettes to minors, the data suggest that noncompliance with this law is important for the maintenance of this health-harmful behavior in nearly half of the adolescent smokers in Brazil. In addition, the study is subject to information bias because all information was self-reported by the participants. However, given that questionnaires were self-administered and anonymity was ensured, ${ }^{(11)}$ at least the influence of parents and/or interviewers on the responses may have been minimized.

The two major questions analyzed in our study were related only to the sale of cigarettes to minors. It is known, however, that there are other tobacco products, such as water pipes, that are very commonly used among adolescents, ${ }^{(27)}$ all of which should be subject to the same restrictions as cigarettes. ${ }^{(7,8)}$ According to data from the PeNSE, ${ }^{(11)}$ the proportions of youth aged 13 to 17 years who reported being smokers and using tobacco products other than cigarettes concomitantly or exclusively were $3 \%$ and $4 \%$, respectively. For those youth, unfortunately, we have no information about attempts to buy these other tobacco products nor about the success of attempts and means of acquisition.

Regarding generalization of the findings to all adolescents in Brazil, it should be borne in mind that the PeNSE ${ }^{(11)}$ was conducted on individuals attending school and that elementary and middle schooling is widely available in the country, thereby reducing potential losses. ${ }^{(28)}$ However, the fact that adolescent smokers are likely to have higher rates of school absenteeism than do adolescent nonsmokers cannot be left out. ${ }^{(29)}$

Our findings may contribute to supporting compliance with existing laws in Brazil that are aimed at reducing smoking initiation and therefore, in the future, may also contribute to reducing cigarette smoking-related morbidity and mortality. The scenario described in the present study indicates the need to stimulate federal, state, and municipal powers to take educational and surveillance measures, including through joint efforts with retail trade bodies and with unions representing the newsstand sector and other commercial sectors. Therefore, it would also be important to motivate agencies such as the Public Prosecutor's Office to negotiate a conduct adjustment term with the tobacco companies supplying the vast network of retailers nationwide, ${ }^{(19)}$ in which the companies agree to take shared responsibility for enforcing the law prohibiting the sale of tobacco products to minors. ${ }^{(7,8)}$ At the same time, it would also be important to mobilize members of the House of Representatives and the Senate to propose and pass a federal law restricting the sale of tobacco products to licensed tobacco stores.

The information presented in this study may also help leverage the implementation of other measures to combat smoking, such as a ban on cigarettes with additives $^{(20)}$ and approval of the protocol to eliminate illicit trade in tobacco products ${ }^{(30)}$; such measures would prevent cigarettes from being available to adolescents in stores and through street vendors

\section{REFERENCES}

1. World Health Organization [homepage on the Internet]. Geneva: World Health Organization [cited 2017 Oct 16]. WHO Framework Convention on Tobacco Control 2003. Available from: http://www. who.int/fctc/text_download/en/index.html

2. Szklo AS, de Almeida LM, Figueiredo VC, Autran M, Malta D, Caixeta $R$, et al. A snapshot of the striking decrease in cigarette smoking prevalence in Brazil between 1989 and 2008. Prev Med. 2012;54(2):162-7. https://doi.org/10.1016/j.ypmed.2011.12.005

3. GBD 2015 Tobacco Collaborators. Smoking prevalence and attributable disease burden in 195 countries and territories, 19902015: a systematic analysis from the Global Burden of Disease Study 2015. Lancet. 2017;389(10082):1885-1906. https://doi.org/10.1016/ S0140-6736(17)30819-X

4. Szklo AS, de Souza MC, Szklo M, de Almeida LM. Smokers in Brazil: who are they? Tob Control. 2016;25(5):564-70. https://doi. org/10.1136/tobaccocontrol-2015-052324

5. Laranjeira R, Madruga CS, Pinsky I, Caetano R, Mitsuhiro SS. Segundo Levantamento Nacional de Álcool e Drogas: Relatório 2012. São Paulo: Instituto Nacional de Ciência e Tecnologia para Políticas Públicas de Álcool e Outras Drogas, UNIFESP; 2014.

6. Instituto Brasileiro de Geografia e Estatística (IBGE) [homepage on the Internet]. Rio de Janeiro: IBGE; [cited 2017 Oct 16]. Pesquisa Nacional de Saúde 2013-Percepção do estado de saúde, estilos de vida e doenças crônicas Brasil, Grandes Regiões e Unidades da Federação. Available from: http://www.ibge.gov.br/home/estatistica/ populacao/pns/2013/default.shtm

7. Ministério Público do Paraná [homepage on the Internet]. Curitiba: o Ministério [cited 2017 Oct 16]. Estatuto da Criança e do Adolescente. Lei $n^{\circ}$ 8.069, de 13 de julho de 1990, e legislação correlata. 9th ed. Brasília : Câmara dos Deputados; 2012. [Adobe Acrobat document, 207 p.]. Available from: http://www.crianca.mppr.mp.br/arquivos/ File/publi/camara/estatuto_crianca_adolescente_9ed.pdf

8. Brasil. Câmara dos Deputados [homepage on the Internet]. Brasilia: a Câmara [cited 2017 Oct 16]. Lei № 10.702, de 14 de julho de 2003
- Publicação Original [about 3 screens]. Available from: http://www2. camara.leg.br/legin/fed/lei/2003/lei-10702-14-julho-2003-487461publicacaooriginal-1-pl.html

9. Instituto Nacional de Câncer José Alencar Gomes da Silva (INCA). A situação do tabagismo no Brasil: dados dos inquéritos do Sistema Internacional de Vigilância, da Organização Mundial da Saúde, realizados no Brasil, entre 2002 e 2009. Rio de Janeiro: INCA; 2011.

10. Instituto Brasileiro de Geografia e Estatística (IBGE). Pesquisa Nacional de Saúde do Escolar: 2012. Rio de Janeiro: IBGE, 2013.

11. Instituto Brasileiro de Geografia e Estatística (IBGE). Pesquisa Nacional de Saúde do Escolar: 2015. Rio de Janeiro: IBGE; 2016.

12. Wacholder S. Binomial regression in GLIM: estimating risk ratio and risk differences. Am J Epidemiol. 1986;123(1):174-84. https://doi org/10.1093/oxfordjournals.aje.a114212

13. Szklo M, Nieto FJ. Epidemiology: beyond the basics. 3rd ed Burlington, MA: Jones \& Bartlett Learning; 2014

14. StataCorp. Stata Statistical Software. Release 12.0. College Station, Texas: StataCorp; 2011.

15. Figueiredo VC, Szklo AS, Costa LC, Kuschnir MC, da Silva TL, Bloch $\mathrm{KV}$, et al. ERICA: smoking prevalence in Brazilian adolescents. Rev Saude Publica. 2016;50 Suppl 1:12s. https://doi.org/10.1590/s015188787.2016050006741

16. Brasil. Ministério da Fazenda [homepage on the Internet]. Brasilia: o Ministério [cited 2017 Oct 16]. Tributação IPI Cigarros-MP 540/2011-Decreto 7.555/2011. [Adobe Acrobat document, 8p.]. Available from: http://www.fazenda.gov.br/noticias/2011/agosto/ Tributacao_IPI_Cigarros_MP_e_DECRETO_Imprensa.pdf

17. Levy D, de Almeida LM, Szklo A. The Brazil SimSmoke policy simulation model: the effect of strong tobacco control policies on smoking prevalence and smoking-attributable deaths in a middle income nation. PLoS Med. 2012;9(11):e1001336. https://doi org/10.1371/journal.pmed.1001336

18. Brasil. Presidência da República. Ministério da Casa Civil. Brasília: a Presidência [cited 2017 Oct 16]. Decreto Nº 8.262, de 31 de maio de 
2014 [about 4 screens]. Available from: http://www.planalto.gov.br/ ccivil_03/_Ato2011-2014/2014/Decreto/D8262.htm

19. Souza Cruz [homepage on the Internet]. Rio de Janeiro: Souza Cruz [cited 2017 Oct 16]. Vendedores da Souza Cruz atendem diretamente cerca de 300 mil varejos em todo o país [about 2 screens]. Available from: http://www.souzacruz.com.br/group/sites/SOU_AG6LVH.nsf/ vwPagesWebLive/DOAGCK8J?opendocument

20. Brasil. Ministério da Saúde. Agência Nacional de Vigilância Sanitária (ANVISA) [homepage on the Internet]. Brasília: o Ministério [cited 2017 Oct 16]. Resolução da Diretoria Colegiada - RDC № 14, de 15 de março de 2012. Publicação Original [Adobe Acrobat document 6p.]. Available from: http://www2.inca.gov.br/wps/wcm/connect/ a054848041f466a297cdd739cf5dede3/RDC_14_2012_COMP.pdf $? \mathrm{MOD}=\mathrm{AJPERES} \& C A C H E I \mathrm{D}=\mathrm{a} 054848041 \uparrow 466 \mathrm{a} 297 \mathrm{cdd} 739 \mathrm{cf} 5 \mathrm{de}$ de3

21. Iglesias RM, Szklo AS, Souza MC, de Almeida LM. Estimating the size of illicit tobacco consumption in Brazil: findings from the global adult tobacco survey. Tob Control. 2017;26(1):53-59. https://doi. org/10.1136/tobaccocontrol-2015-052465

22. Brasil. Presidência da República. Ministério da Casa Civil. Brasília: a Presidência [cited 2017 Oct 16]. Decreto $N^{\circ} 7.212$, de 15 de junho de 2010. Publicação Original. Available from: http://www.planalto.gov. br/ccivil_03/_ato2007-2010/2010/decreto/d7212.htm

23. Brasil. Presidência da República. Ministério da Casa Civil. Brasília: a Presidência [cited 2017 Oct 16]. Lei № 9.294, de 15 de julho de 1996. Publicação Original. Available from: http://www.planalto.gov. br/ccivil_03/leis/L9294.htm

24. Bauer UE, Briss PA, Goodman RA, Bowman BA. Prevention of chronic disease in the 21st century: elimination of the leading preventable causes of premature death and disability in the USA
Lancet. $\quad$ 2014;384(9937):45-52. $\quad$ https://doi.org/10.1016/S01406736(14)60648-6

25. Pinto M, Bardach A, Palacios A, Biz AN, Alcaraz A, Rodríguez B, et al. Carga de doença atribuível ao uso do tabaco no Brasil e potencial impacto do aumento de preços por meio de impostos [monograph on the Internet]. Buenos Aires: Instituto de Efectividad Clínica y Sanitaria; 2017 [cited 2018 Jan 16]. Available from: www.iecs.org ar/tabaco

26. Szklo AS, Iglesias RM, de Souza MC, Szklo M, Cavalcante TM, de Almeida LM. Understanding the relationship between sales of legal cigarettes and deaths: A case-study in Brazil. Prev Med. 2017;94:5559. https://doi.org/10.1016/.ypmed.2016.11.008

27. Szklo AS, Sampaio MM, Fernandes EM, Almeida LM. Smoking of non-cigarette tobacco products by students in three Brazilian cities: should we be worried? [Article in Portuguese]. Cad Saude Publica. 2011;27(11):2271-5. https://doi.org/10.1590/S0102 $311 \times 2011001100020$

28. Instituto Brasileiro de Geografia e Estatística (IBGE) [homepage on the Internet]. Rio de Janeiro: IBGE [cited 2017 Oct 16]. Pesquisa Nacional por Amostra de Domicílios: Síntese de Indicadores 2013, 2nd edition. Available from: http://www.ibge.gov.br/home/estatistica/ populacao/trabalhoerendimento/pnad2013/default_sintese.shtm

29. Levy DE, Winickoff JP, Rigotti NA. School absenteeism among children living with smokers. Pediatrics. 2011;128(4):650-6. https:// doi.org/10.1542/peds.2011-1067

30. WHO Framework Convention on Tobacco Control [homepage on the Internet]. Geneva: World Health Organization; c2017 [cited 2017 Jan 2]. Protocol to Eliminate Illicit Trade in Tobacco Products. Available from: http://www.who.int/fctc/protocol/en/ 